\title{
Stress, anxiety, depressive disorders, and somatisation among lawyers
}

\author{
Stres, lęk, zaburzenia depresyjne i somatyzacja wśród adwokatów \\ Katarzyna S. Chrobak-Kasprzyk ${ }^{1}$ (D) , Jadwiga Jośko-Ochojska² (iD) \\ ${ }^{1}$ Niepubliczny Zakład Opieki Zdrowotnej nMed, Kraków \\ ${ }^{2}$ Department of Environmental Medicine and Epidemiology, Faculty of Medical Sciences, Medical University of Silesia, \\ Katowice, Poland
}

\begin{abstract}
INTRODUCTION: The American Bar Association has published alarming figures, according to which $28 \%$ of lawyers in the USA suffer from depression, $19 \%$ demonstrate symptoms of anxiety, and $21 \%$ have an alcohol problem. Little is known about stress, anxiety, depressive disorders and somatization among Polish lawyers; therefore this paper is the first assessment of these disorders.

MATERIAL AND METHODS: The study covered 206 lawyers who are members of the District Bar Association in Katowice. An anonymous survey was carried out using the 4DSQ questionnaire.

RESULTS: Nearly $22 \%$ of lawyers have an increased level of stress, including $2 \%$ with a severely increased stress level. Somatization correlated strongly with stress, depression and anxiety, and occurred in about $21 \%$ of subjects. The study revealed a statistically significant relationship between the working hours per week and the following subscales: anxiety $(r=0.17 ; p=0.01)$, stress $(r=0.17 ; p=0.01)$, and depression $(r=0.16 ; p=0.02)$. The performed analysis showed a statistically significant difference in the level of depression between women and men $(\mathrm{t}=2.14 ; \mathrm{p}=0.03)$.

CONCLUSIONS: The study is the first assessment of somatization, stress, anxiety, and depressive disorders among lawyers in Poland. High stress levels were found among the subjects, which correlated most significantly with somatization of the musculoskeletal, gastrointestinal, neurological, and cardiovascular systems. Anxiety and depressive disorders were more frequent among lawyers than in the general population, and the number of somatic symptoms increased along with the severity of these disorders. Depressive disorders were more common among men.
\end{abstract}

\section{KEY WORDS}

stress, anxiety, depressive disorders, somatization, lawyers

\section{STRESZCZENIE}

WSTĘP: American Bar Association opublikowało niepokojące dane, iż 28\% prawników w USA cierpi na depresję, 19\% wykazuje objawy lęku, 21\% nadużywa alkoholu. Niewiele wiadomo na temat stresu, lęku, zaburzeń depresyjnych i somatyzacji wśród polskich adwokatów, zatem prezentowana praca jest pierwszą oceną stanu psychicznego i emocjonalnego wspomnianej grupy zawodowej.

$\begin{array}{llll}\text { Received: 01.03.2019 Revised: 22.11.2019 Accepted: 21.12.2019 Published online: 07.08.2020 } & \text { Act }\end{array}$

Address for correspondence: Lek. med. Katarzyna S. Chrobak-Kasprzyk, Niepubliczny Zakład Opieki Zdrowotnej nMed, ul. E. Radzikowskiego 17/2, 31-315 Kraków, Polska, tel. 481262622 00, e-mail: katarzyna.chrobak-kasprzyk@nmed.pl

Copyright ( S Śląski Uniwersytet Medyczny w Katowicach

www.annales.sum.edu.pl 
MATERIA I METODY: Badaniem objęto 206 adwokatów, członków Okręgowej Rady Adwokackiej w Katowicach. Badanie przeprowadzono anonimowo za pomocą kwestionariusza 4DSQ.

WYNIKI: Blisko $22 \%$ adwokatów deklaruje podwyższony poziom stresu, w tym $2 \%$ mocno podwyższony. Somatyzacja korelowała silnie ze stresem, depresją oraz lękiem i występowała u około 21\%. Badanie wykazało istnienie istotnego statystycznie związku pomiędzy tygodniową liczbą godzin pracy a podskalami: lęku $(r=0,17 ; p=0,01)$ stresu $(r=0,17$; $\mathrm{p}=0,01)$ oraz depresji $(\mathrm{r}=0,16 ; \mathrm{p}=0,02)$. Przeprowadzona analiza wykazała istnienie istotnej statystycznie różnicy w poziomie depresji pomiędzy kobietami i mężczyznami $(\mathrm{t}=2,14 ; \mathrm{p}=0,03)$.

WNIOSKI: Przeprowadzone badanie jest pierwszą oceną somatyzacji, stresu, lęku i zaburzeń depresyjnych wśród adwokatów w Polsce. U badanych stwierdzono wysoki poziom stresu, który najsilniej korelował z somatyzacją ze strony układu mięśniowo-szkieletowego, pokarmowego, neurologicznego oraz sercowo-naczyniowego. Niepokój i zaburzenia depresyjne występowały w tej grupie zawodowej częściej niż w populacji ogólnej i wraz ze wzrostem ich nasilenia narastała liczba objawów somatycznych. Zaburzenia depresyjne występowały częściej wśród mężczyzn.

\section{SŁOWA KLUCZOWE}

stres, lęk, zaburzenia depresyjne, somatyzacja, adwokaci

\section{INTRODUCTION}

Little is known about stress, anxiety, and depressive disorders among Polish lawyers. In the Polish literature there are no reports on the prevalence of depressive disorders, anxiety, or somatisation among this occupational group. This paper is the first assessment of the emotional and mental state of lawyers in Poland. The ability to diagnose a patient's mental and emotional state, along with somatic symptoms, is of great importance in further management and treatment. Knowledge of the prevalence of mental disorders and somatisation, supported by knowledge of the factors that increase their prevalence in the legal profession, can effectively contribute to the implementation of prevention programmes and, consequently, to the reduction of their incidence.

The American Bar Association has published alarming data: $28 \%$ of lawyers in the USA suffer from depression, $19 \%$ shows symptoms of anxiety, while $21 \%$ of them abuse alcohol [1]. The surmise that lawyers are more exposed to stress in relation to the general population has been proven by research conducted in the United States [5], which showed that $19 \%$ of lawyers suffer from depression when compared to $3-9 \%$ of the general population. The research results in the United States have forced many legal and public health institutions to undertake a consistent and conscious strategy against depressive disorders, anxiety, and alcoholism among lawyers $[2,3]$.

The above-mentioned data indicate a major problem regarding the prevalence of depressive disorders in relation to the general population, as the incidence of depressive disorders, according to various sources, affects approx. $5-17 \%$ of the general population over a lifetime [4], whereas, according to WHO estimates [5,6], depression affects approx. 350 million people around the world, representing approx. 5-6\% of the world population. In Poland, depression accounts for 3-4\% of all mental disorders, and approximately 1.5 million people suffer from it [7]. For several years, the prevalence rates of depressive disorders have been increasing. This is due to the ever-growing interest in this sphere of he-

\section{WPROWADZENIE}

Niewiele wiadomo na temat stresu, lęku, i zaburzeń depresyjnych wśród polskich adwokatów. W rodzimym piśmiennictwie brak doniesień na temat występowania zaburzeń depresyjnych, lęku czy somatyzacji w tej grupie zawodowej. Prezentowana praca jest pierwszą oceną stanu emocjonalnego i psychicznego adwokatów w Polsce. Umiejętność postawienia diagnozy wraz ze wskazaniem objawów somatycznych ma ogromne znaczenie w dalszym postępowaniu i leczeniu. Wiedza na temat skali zaburzeń psychicznych i somatyzacji, wspierana wiedzą na temat czynników wpływających na zwiększenie częstości ich występowania w zawodzie adwokata, może skutecznie przyczynić się do wdrożenia programów profilaktycznych i w konsekwencji do ich ograniczenia.

American Bar Association opublikowało niepokojące dane, iż 28\% prawników w USA cierpi na depresję, $19 \%$ wykazuje objawy lęku, 21\% nadużywa alkoholu [1]. Podejrzenie, że prawnicy są bardziej narażeni na stres niż ogół populacji, zostało potwierdzone badaniami przeprowadzonymi w Stanach Zjednoczonych [5], według których 19\% adwokatów cierpi na depresję, przy czym skala tej choroby w populacji ogólnej wynosi 9\%. Przytoczone wyniki badań zmusiły wiele instytucji prawniczych i zdrowia publicznego w USA do podjęcia spójnej i świadomej strategii w przeciwdziałaniu zaburzeniom depresyjnym, lękowi i alkoholizmowi w tej grupie zawodowej $[2,3]$.

Powyższe dane wskazują na znaczny problem występowania zaburzeń depresyjnych w stosunku do populacji ogólnej, gdyż częstość zaburzeń depresyjnych według różnych źródeł, w ciągu całego życia dotyka około 5-17\% populacji ogólnej [4], natomiast według szacunków WHO [5,6] depresja dotyka około $350 \mathrm{mln}$ ludzi na całym świecie, tj. około 5-6\% populacji świata. W Polsce depresja stanowi 3-4\% wszystkich rozpoznawanych zaburzeń psychicznych, a cierpi na nią prawdopodobnie 1,5 mln osób [7]. Od kilkunastu lat wskaźniki rozpowszechnienia zaburzeń depresyjnych mają tendencję wzrostową. Wynika to z faktu coraz większego zainteresowania tą sferą zdrowia, większej 
alth, greater detectability, but also the actual increase in the prevalence rate. Not without significance are civilisation factors, an increase in life expectancy as well as in the distribution and availability of medicines and substances for sleep disorders and depression.

The authors of studies conducted in the USA, among the main factors affecting the lawyers' mental health, indicate the pressure of responsibility for human fate, urgent deadlines, public speaking in court and excessive alcohol consumption. Court opponents often force a sudden change in the course of the trial, which involves a great deal of stress, and clients' excessive expectations towards their lawyers cause frustration. The huge competition in the market for legal services should be mentioned as well. In Poland after 2005, i.e. when the Act on opening legal professions entered into force, an increase from 6,191 active lawyers to 18,289 was recorded [8].

Terluin [9], on the basis of the analysis of patients reporting to a primary care physician, identified four dimensions of the most common mental problems in patients, i.e. distress, depression, anxiety, and somatisation. Somatisation is the process of experiencing a mental burden or suffering in the form of somatic complaints that are perceived and interpreted as symptoms of a serious somatic disease. Therefore, the patient may complain about ailments concerning various systems of the human body $[9,10,11]$. The emotional or mental component may be anxiety or depressive disorders. The ability to diagnose the above-mentioned disorders, their differentiation as well as assessment of the prevalence are of great importance in further management and treatment of the patient.

\section{MATERIAL AND METHODS}

The study involved 206 lawyers, including 102 women and 104 men, who are members of the District Bar Council in Katowice. The average age of the respondents was 43 years, the average BMI of the group was 25.15 (Table I). The vast majority of respondents work in their own law firms or are partners in a law firm. The respondents' main areas of activity are representation of a client in court, providing services and assessment for business entities.

In the study group, an anonymous study was conducted using the 4DSQ questionnaire [12], evaluating stress, depression, anxiety, and somatisation (Cronbach's alpha coefficient above 0.8 ).

The 4DSQ questionnaire contains 50 items that cover four scales. The questions included in the questionnaire are similar to those for a medical history; they limit the symptom duration to the last week. The response categories are coded on a 5-point scale.

Data analysis was conducted using the Statistica 10 software package. The qualitative variables were expressed in numbers and percentages; for the quantitative variables, the basic parameters of descriptive statistics, such as mean and standard deviation, were calculated and the minimum/maximum values were gi- wykrywalności, ale też rzeczywistego wzrostu liczby zachorowań. Nie bez znaczenia są tu czynniki cywilizacyjne, wydłużenie średniej długości życia oraz rozpowszechnienie i większa dostępność leków oraz substancji sprzyjających zarówno zaburzeniom snu, jak i depresji.

Autorzy badań przeprowadzonych w USA, pośród głównych czynników wpływających na zdrowie psychiczne adwokatów, wymieniają: presję odpowiedzialności za losy ludzkie, naglące terminy, wystąpienia publiczne w sądzie oraz spożywanie nadmiernych ilości alkoholu. Przeciwnicy sądowi wymuszają często nagłą zmianę przebiegu rozprawy, co wiąże się z dużym stresem, a nadmierne oczekiwania klientów wobec prawników budzą frustrację. Należy wspomnieć o ogromnej konkurencji na rynku usług prawniczych. W Polsce po 2005 r., kiedy w życie weszła ustawa o otwarciu zawodów prawniczych, odnotowano wzrost liczby czynnych adwokatów z 6191 do 18289 [8].

Terluin [9] na podstawie analizy pacjentów zgłaszających się do lekarza podstawowej opieki zdrowotnej zidentyfikował cztery najczęstsze problemy psychiczne pacjentów, tj.: dystres, depresję, lęk i somatyzację. Somatyzacja jest procesem doświadczania i przeżywania obciążenia lub cierpienia psychicznego w postaci dolegliwości somatycznych, które są postrzegane i interpretowane jako objawy poważnej choroby. Chory może zatem uskarżać się na dolegliwości ze strony różnych układów $[9,10,11]$. Komponentą emocjonalną lub psychiczną może być lęk bądź zaburzenia depresyjne. Umiejętność zdiagnozowania tych zaburzeń, ich różnicowanie oraz ocena skali występowania mają ogromne znaczenie w dalszym postępowaniu i leczeniu pacjenta.

\section{MATERIA I METODY}

Badaniem objęto 206 adwokatów, w tym 102 kobiety i 104 mężczyzn, będących członkami Okręgowej Rady Adwokackiej w Katowicach. Średni wiek badanych wynosił 43 lata, średnie BMI grupy wynosiło 25,15 (tab. I). Zdecydowana większość badanych pracuje we własnych kancelariach lub jest wspólnikiem kancelarii. Głównymi obszarami działalności ankietowanych są reprezentacja klienta w sądzie oraz obsługa i opiniowanie podmiotów gospodarczych.

$\mathrm{W}$ wyodrębnionej grupie przeprowadzono anonimowe badanie za pomocą kwestionariusza 4DSQ [12], oceniającego stres, depresję, lęk i somatyzację (współczynnik alfa Cronbacha powyżej 0,8).

Kwestionariusz 4DSQ zawiera 50 pozycji, które obejmują cztery skale. Pytania zawarte w kwestionariuszu przypominają te z wywiadu lekarskiego i ograniczają czas trwania objawów do ostatniego tygodnia. Kategorie odpowiedzi są kodowane w 5-stopniowej skali.

Analizę danych wykonano w pakiecie Statistica 10. Zmienne jakościowe scharakteryzowano za pomocą liczebności i odsetka, a w przypadku zmiennych ilościowych wyliczono podstawowe parametry statystyki opisowej, takie jak średnia, odchylenie standardowe, oraz podano wartości minimalną i maksymalną. Ze 
ven. Due to the size of the group, parametric methods were selected. Pearson's (linear) correlation coefficient, along with a test of significance for this coefficient, was applied to analyse the link among the variables. Intergroup comparisons were made using Student's t-test for independent variables. In the case of failure to meet the assumptions of homogeneity of variance (verified by Levene's test), a test with separate Cochran-Cox variance estimation was applied. The significance level $\alpha=$ 0.05 was assumed. The results were considered statistically significant when the calculated test probability $(\mathrm{p})$ met the inequality $\mathrm{p}<0.05$.

\begin{tabular}{|c|c|c|}
\hline \multirow{2}{*}{ Variable/Zmienna } & \multicolumn{2}{|c|}{ Respondents/Badani $(\mathrm{N}=206)$} \\
\hline & $M \pm S D$ & $\min -\max$ \\
\hline Age[years]/Wiek [w latach] & $43.07 \pm 11.81$ & $29-84$ \\
\hline Weight [kg]/Masa ciała [kg] & $76.30 \pm 16.91$ & $47-134$ \\
\hline Height [cm]/Wysokość ciała [cm] & $173.55 \pm 9.06$ & $156-200$ \\
\hline BMI $\left[\mathrm{kg} / \mathrm{m}^{2}\right]$ & $25.15 \pm 4.42$ & $17.35-40.45$ \\
\hline $\begin{array}{l}\text { Number of years in the profession/ } \\
\text { Liczba lat w zawodzie }\end{array}$ & $15.22 \pm 11.40$ & $1-63$ \\
\hline $\begin{array}{l}\text { Number of working hours per week/ } \\
\text { Liczba godzin pracy na tydzień/ }\end{array}$ & $50.53 \pm 10.37$ & $9-80$ \\
\hline
\end{tabular}

$\mathrm{BMI}$ - body mass index/indeks masy ciała, M - mean/średnia, SD - standard deviation/odchylenie standardowe, min - minimal value/wartość minimalna, max - maximal value/wartość maksymalna

\section{RESULTS}

Undoubtedly, stress attained the highest negative value among the respondents - the moderately increased result was obtained by every fifth respondent, whereas $2 \%$ of the respondents obtained a strongly increased value (Tab. II).

A similar result was obtained for somatisation, whose value - assessed using the 4DSQ scale - constituted $21 \%$ of the respondents. Slightly lower values were obtained for anxiety and depression levels. The levels of depressive disorders occurred in $12 \%$ of the respondents: moderately increased - over $9.22 \%$, strongly increased - almost $2 \%$. względu na liczebność grupy wybrano metody parametryczne. Do analiz związku pomiędzy zmiennymi wykorzystano współczynnik korelacji liniowej Pearsona wraz z testem istotności dla tego współczynnika. Porównań międzygrupowych dokonano przy użyciu testu t dla zmiennych niezależnych. W sytuacji niespełnienia założenia o jednorodności wariancji (weryfikowane testem Levene'a) stosowano test $\mathrm{z}$ oddzielną estymacją wariancji Cochrana-Coxa. Założono poziom istotności alpha $=0,05$. Za istotne statystycznie uznano wyniki, gdy wyliczone prawdopodobieństwo testowe $\mathrm{p}$ spełniało nierówność $\mathrm{p}<0,05$.

\section{WYNIKI}

Niewątpliwie najwyższą niekorzystną wartość wśród badanych osiągnął poziom stresu - wynik średnio podwyższony uzyskał co piąty badany, mocno podwyższony występował u 2\% (tab. II).

Podobny wynik uzyskano dla somatyzacji, której częstość występowania oceniana za pomocą skali 4DSQ wyniosła $21 \%$ badanych. Nieco niższe wartości osiągnięto dla poziomu lęku i depresji. Zaburzenie depresyjne wystąiły u $12 \%$, przy czym na poziomie średnio podwyższonym u ponad $9,22 \%$ badanych, natomiast mocno podwyższonym u blisko $2 \%$.

Wykazano istotną statystycznie korelację $(\mathrm{p}<0,001)$ współwystępowania somatyzacji ze stresem, depresją i lękiem. Uzyskano dodatnią zależność dla niepokoju i depresji o przeciętnej sile oraz dla stresu o dużej sile. Z uzyskanych danych wynika, że w grupie adwokatów wraz ze wzrostem zaburzeń depresyjnych, lęku, a w szczególności poziomu stresu, rosła liczba zgłaszanych objawów somatycznych. Najczęściej zgłaszanymi dolegliwościami, występującymi u więcej niż połowy ankietowanych, były objawy ze strony układu mięśniowo-szkieletowego (bóle pleców, mięśni i szyi), u co trzeciego badanego ze strony układu pokarmowego (wzdęcia brzucha, nudności, zaburzenia przewodu pokarmowego), oraz neurologiczne, tj. ból głowy u blisko $66 \%$, a także zawroty głowy u $35 \%$.

Somatyzacja w obrębie układu sercowo-naczyniowego, w postaci bólu w okolicy klatki piersiowej, kołatania serca, ucisku oraz duszności, występowała śred-

Table II. Somatization, anxiety, stress by 4DSQ scale Tabela II. Somatyzacja, lęk, depresja i stres według przedziałów interpretacyjnych skali 4DSQ

\begin{tabular}{|c|c|c|c|c|c|c|c|c|}
\hline \multirow[t]{2}{*}{ Result/Wynik } & \multicolumn{2}{|c|}{$\begin{array}{c}\text { Somatization/Somatyzacja } \\
M-7.03, S D=5.45 \\
M i n-0, \text { Max-27 }\end{array}$} & \multicolumn{2}{|c|}{$\begin{array}{c}\text { Anxiety/Lęk } \\
\text { M-1.54, SD = 2.01 } \\
\text { Min-0, Max-12 }\end{array}$} & \multicolumn{2}{|c|}{$\begin{array}{c}\text { Depression/Depresja } \\
\text { M-0.81, Sd = } 1.49 \\
\text { Min-0, Max-10 }\end{array}$} & \multicolumn{2}{|c|}{$\begin{array}{c}\text { Stress/Stres } \\
\text { M-6.29, SD = } 4.62 \\
\text { Min-0, Max-25 }\end{array}$} \\
\hline & $\mathrm{N}$ & $\%$ & $\mathrm{~N}$ & $\%$ & $\mathbf{N}$ & $\%$ & $\mathrm{~N}$ & $\%$ \\
\hline $\begin{array}{l}\text { Normal value according to } 4 \mathrm{DSQ} \text { scale/ } \\
\text { Norma wg skali } 4 \mathrm{DSQ}\end{array}$ & 163 & 79.13 & 178 & 86.41 & 183 & 88.83 & 163 & 79.13 \\
\hline $\begin{array}{l}\text { Moderately increased/Średnio } \\
\text { podwyższony }\end{array}$ & 34 & 16.50 & 26 & 12.62 & 19 & 9.22 & 39 & 18.93 \\
\hline $\begin{array}{l}\text { Significantly increased/Mocno } \\
\text { podwyższony }\end{array}$ & 9 & 4.37 & 2 & 0.97 & 4 & 1.94 & 4 & 1.94 \\
\hline
\end{tabular}


There was a statistically significant correlation $(\mathrm{p}<$ 0.001 ) for the co-occurrence of somatisation with stress, depression, and anxiety. Positive correlations were obtained for average anxiety and depression intensity, and for acute stress.

Table III. Correlation with stress, anxiety, depressive disorders Tabela III. Korelacja somatyzacji z lekkiem, depresja oraz stresem

\begin{tabular}{lcc}
\hline \multicolumn{1}{c}{ Pair of variables/Para zmiennych } & $\mathrm{r}$ & $\mathrm{p}$ \\
\hline Somatization \& anxiety/Somatyzacja i lęk & 0.38 & 0.000 \\
$\begin{array}{l}\text { Somatization \& depressive disorders/Somatyzacja i } \\
\text { depresja }\end{array}$ & 0.34 & 0.000 \\
Somatization \& stress/Somatyzacja i stres & 0.58 & 0.000 \\
\hline
\end{tabular}

The data obtained show that as depressive disorders, anxiety and, in particular, stress levels among lawyers increased, the number of reported somatic symptoms continued to grow. The most frequently reported complaints, occurring in more than half of the respondents, were symptoms concerning the musculoskeletal system, including backache, muscle, and neck pains. Gastrointestinal symptoms, such as abdominal bloating, nausea, and gastrointestinal disorders, occurred in every third subject. The most common neurological symptoms included: headache (occurring in almost $66 \%$ of the respondents) and dizziness (35\%).

Table IV. Incidence of somatization expressed in percentage Tabela IV. Częstość występowania somatyzacji wyrażona w procentach

\begin{tabular}{lc}
\hline \multicolumn{1}{c}{ Somatyzacja/Somatization } & {$[\%]$} \\
\hline Severe or mild/Silne lub lekkie zawroty głowy & 34.99 \\
\hline Muscle pains/Bóle mięśni & 55.66 \\
\hline Syncope/Omdlenie & 4.77 \\
\hline Neck pains/Bóle szyi & 55.99 \\
\hline Back pains/Bóle pleców & 71.11 \\
\hline Excessive sweating/Nadmierne pocenie się & 37.77 \\
\hline Palpitations/Kołatanie serca & 22.96 \\
\hline Headaches/Bóle głowy & 65.59 \\
\hline Flatulence/ Wzdęcia brzucha & 43.88 \\
\hline Blurry vision or seeing spots/Zamglone widzenie lub plamy & 23.87 \\
przed oczami & \\
\hline $\begin{array}{l}\text { Dyspnoea/Duszności } \\
\text { Nausea/Nudności }\end{array}$ & 14.99 \\
\hline $\begin{array}{l}\text { Stomachaches or pain in abdominal region/Bóle brzucha lub } \\
\text { w okolicy żołądka }\end{array}$ & 25.58 \\
\hline Tingling in fingers/Mrowienie w palcach & 28.78 \\
\hline $\begin{array}{l}\text { Chest pressure or tension/Ucisk lub napięcie w klatce } \\
\text { piersiowej }\end{array}$ & 24.66 \\
\hline Chest pains/ Bóle w klatce piersiowej & $19.97 \%$ \\
\hline
\end{tabular}

Somatisation within the cardiovascular system - in the form of chest pain, palpitations, tightness in the chest and dyspnoea - occurred in $20 \%$ of the subjects on average. The least reported symptom was fainting (4.77\%). In addition, studies were conducted where the severity of depressive disorders and somatisation as well as anxiety and stress were correlated with such variables as: age, number of years in the profession, average weekly working hours and gender. With regard to these disorders and anxiety, no correlation was found nio u 20\% badanych. Najrzadziej zgłaszano omdlenie $(4,77 \%)$

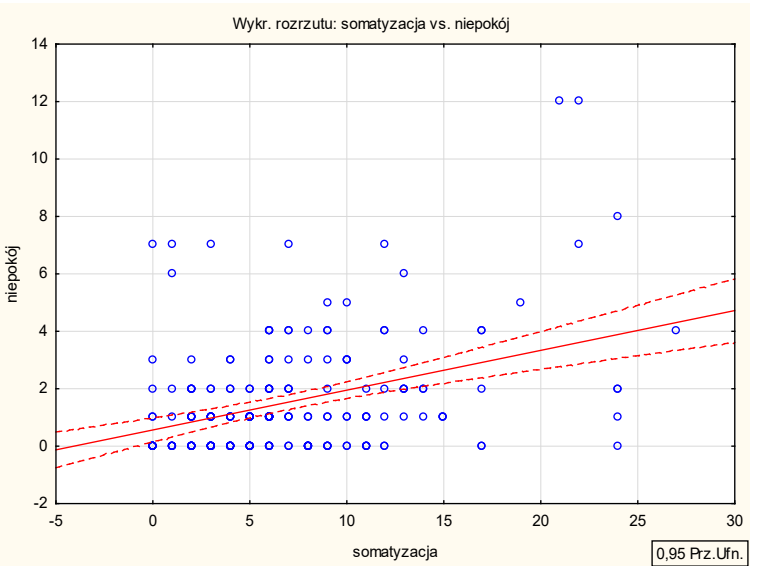

Fig. 1. Graph demonstrating range of somatization and anxiety. Ryc. 1. Wykres rozrzutu somatyzacji i lęku.

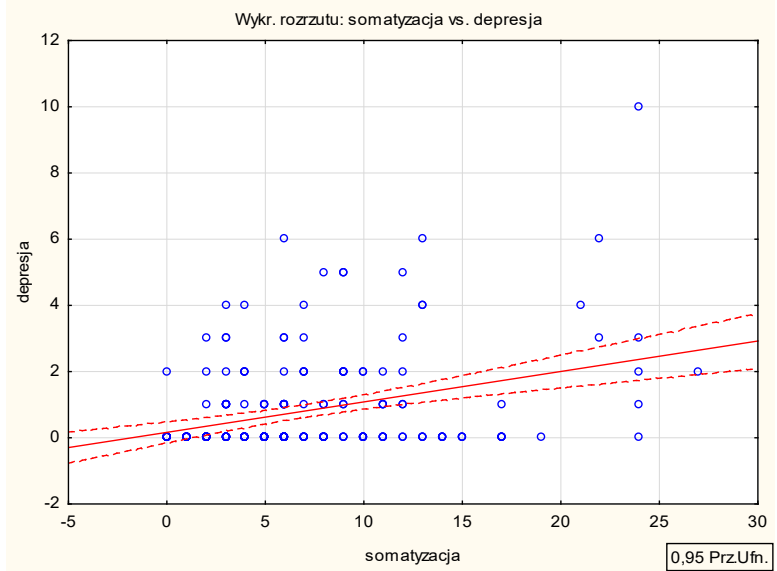

Fig. 2. Graph demonstrating range of somatization and depressive disorders.

Ryc. 2. Wykres rozrzutu somatyzacji i zaburzeń depresyjnych.

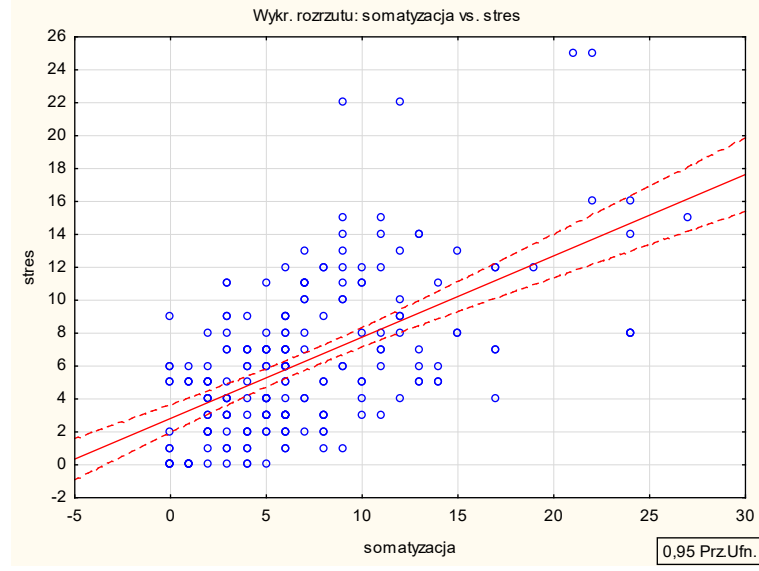

Fig. 3. Graph demonstrating range of somatization and stress. Ryc. 3. Wykres rozrzutu somatyzacji i stresu.

Przeprowadzono również badania, w których poddano analizie korelację nasilenia zaburzeń depresyjnych i so- 
between them and the age of the lawyers or their seniority in the office.

\begin{tabular}{|c|c|c|}
\hline Pairs of variables/Pary zmiennych & $r$ & $p$ \\
\hline $\begin{array}{l}\text { Somatization vs. number of working hours/week/ } \\
\text { Somatyzacja a licz. godzin pracy/tydzień }\end{array}$ & 0.12 & 0.087 \\
\hline $\begin{array}{l}\text { Anxiety vs. number of working hours/week/Lęk a licz. } \\
\text { godzin pracy/tydzień }\end{array}$ & 0.17 & 0.016 \\
\hline $\begin{array}{l}\text { Depression vs. number of working hours/week/ } \\
\text { Depresja a licz. godzin pracy/tydzień }\end{array}$ & 0.16 & 0.023 \\
\hline $\begin{array}{l}\text { Stress vs. number of working hours/week/Stres a licz. } \\
\text { godzin pracy/tydzień }\end{array}$ & 0.17 & 0.013 \\
\hline
\end{tabular}

The analysis conducted using Pearson's (linear) correlation coefficient $r$ showed a statistically significant link between the average weekly working hours and the following subscales: anxiety $(\mathrm{r}=0.17 ; \mathrm{p}=0.01)$, stress $(\mathrm{r}=0.17 ; \mathrm{p}=0.01)$ and depression $(\mathrm{r}=0.16 ; \mathrm{p}=0.02)$. In all cases there is a positive correlation, which means that as the average weekly number of working hours continues to grow, anxiety, stress and depressive disorders among the respondents increase.

Additionally, the analysis has shown that there is a statistically significant difference in the level of depression between women and men $(t=2.14 ; p=0.03)$. The values of calculated arithmetic means indicate a higher level of depressive disorders in the male group. For the remaining disorders, the results were statistically insignificant.

\section{DISCUSSION}

The mental health aspects of the Polish lawyers assessed in this study are similar to the results obtained among lawyers from the United States $[1,2]$. The nearest value to the American study was obtained for elevated levels of stress, as $23 \%$ of American attorneys and $21 \%$ of Polish lawyers assessed the feeling of stress at medium and high levels. In a situation where every fifth lawyer has an elevated level of stress, it is reasonable to study in detail whether it is periodically experienced stress or chronic stress, as well as to find out how the subjects manage stress. Regular exposure to stress affects well-being, commitment to work and can reduce the mobilization to act. A negative emotional state may contribute to weakening of general immunity and, in a secondary way, to deterioration of health, including severe depression or occupational burnout in lawyers $[11,13,14,15]$. The authors of the study, whose aim was to investigate the links between occupational burnout in lawyers and stress, showed that the higher the exposure to stress, the higher the risk of occupational burnout. Interestingly, stress was related to low pay as compared to the commitment to work [14]. The obtained result indicates an increased level of stress among the Polish population of lawyers, which may translate into negative effects at work, disastrous for the legal profession such matyzacji, lęku oraz stresu ze zmiennymi, takimi jak: wiek, liczba lat w zawodzie, średnia tygodniowa liczba godzin pracy oraz płeć. Nie stwierdzono zależności pomiędzy tymi zaburzeniami, lękiem i wiekiem badanych oraz stażem pracy.

\begin{tabular}{|c|c|c|c|c|c|c|}
\hline \multirow{2}{*}{ Variables/Zmienna } & \multicolumn{2}{|c|}{$\begin{array}{l}\text { Mean/ } \\
\text { Średnia }\end{array}$} & \multirow[t]{2}{*}{$\mathrm{t}$} & \multirow{2}{*}{$\mathrm{p}$} & \multicolumn{2}{|c|}{ SD } \\
\hline & W/K & M & & & W/K & M \\
\hline $\begin{array}{l}\text { Somatyzacja/ } \\
\text { Somatization }\end{array}$ & 6.87 & 7.18 & -0.41 & 0.684 & 4.95 & 5.92 \\
\hline Anxiety/Lęk & 1.51 & 1.57 & -0.20 & 0.838 & 2.18 & 1.83 \\
\hline Depression/Depresja & 0.59 & 1.03 & -2.14 & 0.034 & 1.21 & 1.70 \\
\hline Stress/Stres & 6.39 & 6.19 & 0.31 & 0.758 & 4.92 & 4.34 \\
\hline
\end{tabular}

Analiza przeprowadzona za pomocą współczynnika korelacji liniowej r Pearsona wskazała istnienie istotnego statystycznie związku pomiędzy średnią tygodniową liczbą godzin pracy a podskalami: niepokoju $(r=0,17 ; p=0,01)$, stresu $(r=0,17 ; p=0,01)$ oraz depresji $(\mathrm{r}=0,16 ; \mathrm{p}=0,02)$. We wszystkich przypadkach korelacja była dodatnia, co oznacza, że wraz ze zwiększającą się średnią tygodniową liczbą godzin w pracy rosną lęk, stres i zaburzenia depresyjne wśród ankietowanych.

Analiza wykazała również istnienie istotnej statystycznie różnicy w poziomie depresji pomiędzy kobietami i mężczyznami $(\mathrm{t}=2,14 ; \mathrm{p}=0,03)$. Wartości wyliczonych średnich arytmetycznych wskazują na wyższy poziom zaburzeń depresyjnych $\mathrm{w}$ grupie mężczyzn. W przypadku pozostałych zaburzeń uzyskano wyniki nieistotne statystycznie.

\section{DYSKUSJA}

Ocenione $\mathrm{w}$ badaniu aspekty zdrowia psychicznego polskich adwokatów są zbieżne $\mathrm{z}$ wynikami przeprowadzonych wśród prawników ze Stanów Zjednoczonych [1,2]. Wartość najbardziej zbliżoną do amerykańskch badań uzyskano dla podwyższonego poziomu stresu, bowiem $23 \%$ amerykańskich prawników i $21 \%$ polskich adwokatów oceniło odczuwanie stresu na średnio i mocno podwyższonym poziomie. W sytuacji, kiedy u co piątego adwokata stwierdza się podwyższony poziom stresu, zasadne jest pogłębienie badania o informację, czy jest to stres doświadczany okresowo, czy przewlekły oraz uzyskanie danych na temat, jak badani radzą sobie ze stresem. Regularna ekspozycja na stres wpływa negatywnie na dobrostan, zaangażowanie w pracy i mobilizację do działania. Zły stan emocjonalny może przyczynić się do obniżenia ogólnej odporności i wtórnie przyczynić do pogorszenia stanu zdrowia, włącznie z ciężką depresją bądź wypaleniem zawodowym $[11,13,14,15]$. Autorzy badania, którego celem było zbadanie powiązań między wypaleniem zawodowym prawników a stresem, wykazali, że im większa ekspozycja na stres, tym większe ryzyko wypalenia zawodowego. Co ciekawe, stres miał związek ze zbyt 
as aversion to clients, reduced concentration, impaired memory and creative thinking, or increased frustration. In the studied group of lawyers headaches, muscle pain, backache, and neck pain, as well as symptoms from other systems of the human body prevailed, co-occurring with depressive disorders and anxiety. The subjects reported such gastrointestinal symptoms as abdominal bloating, nausea and gastrointestinal disorders, which occurred in every third subject. The most common neurological symptoms were headaches and dizziness, whereas the cardiovascular conditions included chest pain, palpitations, tightness in the chest and dyspnoea. The data presented in this article indicate that somatisation is strongly correlated with stress, anxiety, and depressive disorders in the study occupational group. With the increase in the level of mental disorders, the number of somatic symptoms reported by the subjects continued to grow.

Somatic diseases may be the cause of the reported complaints, however, mental disorders co-occurred with somatic symptoms to an equal extent in the study group and may suggest their psychogenic nature. The distinction between psychogenic and somatic diseases is never obvious, but it is important to emphasise the overlap of mental disorders with somatisation among the subjects. According to data presented by Williams D. [16], somatisation in the general population is $4-12 \%$, and in the population of patients reporting to the primary care physician the median of somatisation is $16.6 \%$. Somatisation often begins at puberty. Patients with somatisation experience a significant incapacity and role-playing disability. They also spend more days in bed per month than patients with other significant somatic conditions.

In the presented results, somatisation affected as much as $21 \%$ of lawyers, which means that it is more frequent in this group than in the general population. The literature lacks data on the incidence of somatisation among lawyers, thus our evaluation of the phenomenon broadens the knowledge of its scale and is the first assessment among this occupational group. The severity of psychosomatic symptoms in the study occupational group requires from physicians knowledge of how to search for the emotional and mental component of symptoms, as well as arouses the need to explain to the patient the mechanism of their occurrence. After excluding the organic causes responsible for the symptoms and diagnosing the effect of psychological factors on somatic disease, the physician should implement therapy. For the legal profession, training on stress and anxiety management, sleep hygiene and safety regarding working time could be significant.

The studies revealed a higher percentage of depressive disorders when compared to the general population, and a lower percentage when compared to this occupational group in the USA. Nevertheless, it is difficult to compare the results obtained from American research due to the larger size of the study group in the USA. A very interesting phenomenon concerning depressive disorders has been observed in a larger group of men (in niskim wynagrodzeniem w stosunku do zaangażowania w pracę [14]. Otrzymany przez autorów wynik wskazuje na podwyższony poziom stresu wśród polskiej populacji prawników, co może przełożyć się na negatywne skutki w pracy, tak zgubne w zawodzie prawnika, jak: niechęć do klientów, obniżenie koncentracji, zaburzenia pamięci i myślenia kreatywnego czy nasilenie frustracji.

W grupie badanych adwokatów dominował ból głowy, mięśni, pleców, szyi oraz objawy ze strony innych układów, współwystępujące z zaburzeniami depresyjnymi oraz lękiem. Badani wskazywali na dolegliwości ze strony układu pokarmowego, takie jak: wzdęcia brzucha, nudności, zaburzenia przewodu pokarmowego, które wystąpiły u co trzeciego badanego. Wśród objawów neurologicznych dominowały ból oraz zawroty głowy, natomiast dolegliwości układu sercowo-naczyniowego występowały pod postacią bólu w okolicy klatki piersiowej, kołatania serca, ucisku oraz duszności. Przedstawione dane wskazują, że somatyzacja silnie koreluje ze stresem, lękiem i zaburzeniami depresyjnymi w badanej grupie zawodowej. Wraz ze wzrostem poziomu zaburzeń psychicznych rosła liczba zgłaszanych przez badanych objawów somatycznych. Podłożem zgłaszanych dolegliwości mogą być choroby somatyczne, przy czym w badanej grupie zaburzenia psychiczne współwystępowały na równi z objawami somatycznymi, dlatego mogą sugerować ich psychogenny charakter. Rozróżnienie między chorobą psychogenną a somatyczną nie jest oczywiste, jednak należy podkreślić fakt zazębiania się zaburzeń psychicznych z somatyzacją wśród badanych. Według danych zaprezentowanych przez Williams D. [16] somatyzacja w populacji ogólnej wynosi 4-12\%, a w populacji chorych zgłaszających się do lekarza podstawowej opieki zdrowotnej $16,6 \%$. Somatyzacja często rozpoczyna się w wieku dojrzewania. Pacjenci dotknięci nią odczuwają znaczną niesprawność i upośledzenie w zakresie pełnienia ról oraz spędzają w łóżku więcej dni w miesiącu niż chorzy na inne istotne schorzenia.

W zaprezentowanych wynikach somatyzacja dotyczyła aż $21 \%$ prawników, czyli statystycznie większej liczby osób niż w populacji ogólnej. W piśmiennictwie brak danych na temat występowania somatyzacji wśród polskich prawników, zatem podjęta przez autorów ocena zjawiska poszerza wiedzę na temat jego skali i stanowi pierwszą analizę dotyczącą tej grupy zawodowej. Nasilenie objawów psychosomatycznych wśród badanych wymaga od lekarzy wiedzy na temat poszukiwania emocjonalnej i psychicznej komponenty objawów oraz budzi potrzebę wyjaśnienia pacjentowi mechanizmu ich powstawania. Po wykluczeniu przyczyn organicznych, odpowiedzialnych za objawy, oraz rozpoznaniu wpływu czynników psychologicznych na chorobę somatyczną lekarz powinien wdrożyć terapię. W przypadku zawodu adwokata istotne mogłyby się okazać szkolenia dotyczące radzenia sobie ze stresem, lękiem, higieny snu i czasu pracy.

Wyniki przeprowadzonych badań wskazują na wyższy procent zaburzeń depresyjnych w stosunku do populacji 
the general population, women suffer from depression more frequently). The incidence of these disorders was not correlated with the lawyers' seniority in the office or their biological age. Since tests for depression were merely screening tests, it is advisable to make lawyers aware that in the case of any depressive disorder, they should see a psychotherapist or psychiatrist as early as possible - before full-blown depression or occupational burnout develops.

The studies have shown that as the number of hours spent at work per week continues to grow, the severity of depressive disorders, anxiety, and stress increase. This result is part of numerous studies that prove the strong link between excessive workload and mental well-being. By controlling the psychogenic factors and keeping them at an optimal level [9], we can influence mental health behaviour $[17,18]$. Referring to the results of the survey, it would be advisable to educate the study occupational group on optimal working time and to indicate the importance of relaxation techniques and rest for their health.

In conclusion, it is important to remember that lawyers comprise a group more exposed to depressive disorders, somatisation, stress, and anxiety than the general population. A model of pro-healthy behaviour among lawyers, which takes into account all the factors that may affect mental health, should be developed. The lawyers' knowledge of the possible health risks arising from their legal profession, supported by a mental health education programme, would certainly contribute to reducing the incidence of the above-mentioned disorders. Assessment of the patient's mental and emotional state during routine history taking should always be made as it can significantly affect the diagnosis and treatment. Excluding the organic cause, responsible for the reported somatic symptoms, by an investigator should induce the physician to refer the patient to further consultations regarding the patient's mental state. The ill health of the study occupational group is not only a consequence suffered by the lawyers themselves - the implications of untreated disorders as well as the co-existence of somatic and mental diseases is a significant burden on the health care system.

\section{CONCLUSIONS}

1. This study is the first assessment of somatisation, stress, anxiety, and depressive disorders among lawyers in Poland.

2. Among the subjects, an increased level of stress was found, which most strongly correlated with somatisation regarding the musculoskeletal, digestive, neurological and cardiovascular systems.

3. Anxiety and depressive disorders occurred more often among lawyers than in the general population, and with an increase in their severity, the number of somatic symptoms continued to grow.

4. Depressive disorders were more common among men. ogólnej, natomiast niższy w odniesieniu do tej grupy zawodowej w USA. Trudno jednak porównać otrzymane wyniki do badań amerykańskich ze względu na większą liczebność badanej populacji w USA. Zaobserwowano również bardzo ciekawe zjawisko częstego występowania zaburzeń depresyjnych wśród mężczyzn, gdzie w populacji ogólnej na depresję częściej chorują kobiety. Częstość występowania zaburzeń nie korelowała ze stażem pracy adwokatów ani wiekiem biologicznym. Ponieważ badania depresji miały jedynie charakter przesiewowy, wskazane jest, aby w ramach profilaktyki uświadamiać adwokatów o konieczności zgłoszenia się do psychoterapeuty lub lekarza psychiatry w przypadku jakichkolwiek zaburzeń depresyjnych, w celu otrzymania pomocy jak najwcześniej, zanim rozwinie się depresja pełnoobjawowa lub wypalenie zawodowe.

Badania wykazały, że wraz ze wzrostem liczby godzin spędzanych tygodniowo w pracy, wzrasta nasilenie zaburzeń depresyjnych, lęku oraz stresu. Wynik ten wpisuje się w liczne badania potwierdzające silny związek pomiędzy nadmiernym obciążeniem pracą a dobrostanem psychicznym. Poprzez kontrolę czynników psychogennych oraz utrzymanie ich na optymalnym poziomie [9] można wpłynąć na zachowanie zdrowia psychicznego [17,18]. Odnosząc się do wyniku badania, wskazana byłaby edukacja wśród tej grupy zawodowej na temat optymalnego czasu pracy oraz wskazania znaczenia technik relaksacyjnych i odpoczynku na stan zdrowia.

Podsumowując należy pamiętać, że adwokaci są grupą bardziej narażoną na zaburzenia depresyjne i somatyzację, stres oraz lęk niż populacja ogólna. Należy wypracować model zachowania prozdrowotnego wśród prawników uwzględniający wszystkie czynniki mogące wpływać na stan zdrowia psychicznego. Wiedza prawników na temat możliwych zagrożeń dla stanu zdrowia, wynikających z wykonywanej profesji, wspierana programem edukacji higieny zdrowia psychicznego, z pewnością przyczyniłaby się do zmniejszenia częstości występowania wymienionych zaburzeń. Bardzo istotne jest, aby lekarz zawsze podczas rutynowego zbierania wywiadu dokonywał oceny stanu psychicznego i emocjonalnego pacjenta, gdyż może on znacząco wpływać na diagnozę i sposób leczenia. Wykluczenie przez badającego przyczyny organicznej odpowiedzialnej za zgłaszane objawy somatyczne powinno nakłonić lekarza do skierowania chorego na dalsze konsultacje obejmujące stan psychiczny pacjenta. Cenę za zły stan zdrowia badanej grupy zawodowej, ponoszą nie tylko sami adwokaci. Konsekwencją braku leczenia zaburzeń oraz współistniejących chorób somatycznych i psychicznych jest znaczne obciążenie systemu ochrony zdrowia.

\section{WNIOSKI}

1. Przeprowadzone badanie jest pierwszą w Polsce oceną somatyzacji, stresu, lęku i zaburzeń depresyjnych w grupie zawodowej adwokatów. 
5. A correlation was found between the prevalence of the above-mentioned disorders, anxiety, and the average weekly working hours, whereas no correlation was found between the seniority of the office and biological age.

6. Both the assessment of the lawyers' mental health and the existence of a link between stress, anxiety, depressive disorders, and general health raise the need for preventive programmes and training on stress management and safety regarding working time.

\section{Author's contribution}

Study design - K. Chrobak-Kasprzyk, J. Jośko-Ochojska

Data collection - K. Chrobak-Kasprzyk, J. Jośko-Ochojska

Data interpretation - K. Chrobak-Kasprzyk, J. Jośko-Ochojska

Statistical analysis - K. Chrobak-Kasprzyk

Manuscript preparation - K. Chrobak-Kasprzyk, J. Jośko-Ochojska
2. Wśród badanych stwierdzono podwyższony poziom stresu, który najsilniej korelował z somatyzacją ze strony układów mięśniowo-szkieletowego, pokarmowego, neurologicznego oraz sercowo-naczyniowego.

3. Lęk oraz zaburzenia depresyjne występowały wśród adwokatów częściej niż w populacji ogólnej. Wraz ze wzrostem nasilenia narastała liczba objawów somatycznych.

4. Zaburzenia depresyjne występowały częściej wśród mężczyzn.

5. Wykazano związek pomiędzy częstością występowania wymienionych zaburzeń, lękiem a średnia tygodniowa liczba godzin pracy, natomiast nie stwierdzono korelacji ze stażem pracy i wiekiem biologicznym.

6. Przeprowadzona ocena zdrowia psychicznego adwokatów oraz istnienie związku pomiędzy występowaniem stresu, lęku, zaburzeń depresyjnych a ogólnym stanem zdrowia rodzi konieczność wprowadzenia profilaktycznych programów oraz szkoleń z zakresu radzenia sobie ze stresem i higieny czasu pracy.

\section{REFERENCES}

1. Krill P., Johnson R., Albert L. The Prevalence of Substance Use and Other Mental Health Concerns Among American Attorneys. J. Addict. Med. 2016 10(1): 46-52, doi: 10.1097/ADM.0000000000000182.

2. Coyle M., Bree Buchanan J. National task force on lawyer well-being Creating a Movement To Improve Well-Being in the Legal Profession. The Path to Lawyer Well-Being: Practical Recommendations for Positive Change.

3. Bogowicz P., Ferguson J., Gilvarry E., Kamali F., Kaner E., Newbury-Birch D. Alcohol and other substance use among medical and law students at a UK university: a cross-sectional questionnaire survey. Postgrad. Med. J. 2018; 94(1109): 131-136, doi: 10.1136/postgradmedj-2017-135136.

4. Kryteria diagnostyczne zaburzeń psychicznych DSM-5. Red. P. Gałecki, M. Pilecki, J. Rymaszewska, A. Szulc, A. Sidorowicz, J. Wciórka. Urban \& Partner. Wrocław 2018.

5. http://www.who.int/. Światowa Organizacja Zdrowia. 2018 [dostęp 26.02.2019].

6. http://www.who.int/news-room/fact-sheets/detail/depression. WHO [dostęp: 26.02.2019]

7. Epidemiologia zaburzeń psychiatrycznych i dostępność psychiatrycznej opieki zdrowotnej EZOP-Polska. Instytut Psychiatrii i Neurologii. Akademi Medyczna we Wrocławiu. Wrocław 2012.

8. http://www.nra.pl/. Krajowa Rada Adwokacka. Rejestr Adwokatów. 2018 [dostęp: 26.02.2019]

9. Sitnikova K., Dijkstra-Kersten S., Mokkink L., Terluin B., Marwijk H., Leone S., van der Horst H., van der Wouden J. Systematic review of measurement properties of questionnaires measuring somatization in primary care patients. J Psychosom Res. 2017; 103: 42-62, doi: 10.1016/j.jpsychores.2017.10.005. 10. Graninger M. Psychosomatic medicine - viability of a discipline. Wien Med. Wochenschr. 2018; 168(3-4): 51, doi: 10.1007/s10354-017-0599-6.

11. Straub R., Cutolo M.,. Psychoneuroimmunology-developments in stress research. Wien Med. Wochenschr. 2018; 168(3-4): 76-84, doi: 10.1007/s10354 017-0574-2.

12. Czachowski S., Izdebski A., Terluin B., Izdebski P. Walidacja kwestionariusza 4DSQ mierzaçego dystres, depresję, lęk i somatyzycję w Polsce. Probl Med. Rodzj. 2013; 14(4): 14-20.

13. Levin A., Albert L., Besser A., Smith D., Zelenski A., Rosenkranz S., Neria Y. Secondary traumatic stress in attorneys and their administrative support staff working with trauma-exposed clients. J. Nerv. Ment. Dis. 2011; 199(12) 946-955, doi: 10.1097/NMD.0b013e3182392c26.

14. Tsai F., Chan C. Occupational stress and burnout of judges and procurators. Int. Arch. Occup. Environ Health 2010; 83(2): 133-142, doi: 10.1007 s00420-009-0454-1.

15. Tsai F., Huang W., Chan C. Occupational stress and burnout of lawyers. J. Occup. Health 2009; 51(5): 443-450, doi: 10.1539/joh.18179.

16. Lewis P., Mazzoni P.,. Merritt Neurologia. [book auth.] S.A. Mayer E.D. Louis. 13. 2018, 175, pp. 1178-1181.

17. Shimada F., Ohira Y., Hirota Y., Ikegami A. , Kondo T., Shikino K., Suzuk S., Noda K., Uehara T., Ikusaka M. Anxiety and depression in general prac-

tice outpatients: the long-term change process. Int. J. Gen. Med. 2018; 9(11): 55-63, doi: 10.2147/IJGM.S130025.

18. Coppens E., Van Audenhove C., Gusmão R., Purebl G., Székely A., Maxwell M., Koburger N., Arensman E., Hegerl U. Effectiveness of General Practitioner training to improve suicide awareness and knowledge and skills towards depression. J. Affect. Disord. 2018; 227: 17-23, doi: 10.1016/j.jad.2017.09.039. 19. https://www.nimh.nih.gov/index.shtml. National Institute of Mental Health: Major Depression. 2018. https://www.nimh.nih.gov/health/statistics/major-depression.shtml [dostęp: 26.02.2019].

20. Defazio G., Pastore A., Pellicciari R., Pierri G., Gigante AF., Fabio G., Superbo M., Margari F. Personality disorders and somatization in functional and organic movement disorders. Psychiatry Res. 2017; 257: 227-229, doi: 10.1016/j.psychres.2017.07.068.

21. Linden M., Muschalla B., Noack N., Heintze C., Doepfmer S. Treatment Changes in General Practice Patients With Chronic Mental Disorders Following a Psychiatric-Psychosomatic Consultation. Health Serv. Res. Manag. Epidemiol. 2018; 15(5): 23333392818758523, doi: 10.1177/2333392818758523. 22. Sinnema H., Terluin B., Volker D., Wensing M., van Balkom A. Factors contributing to the recognition of anxiety and depression in general practice. BMC Fam. Pract. 2018; 19(1): 99, doi: 10.1186/s12875-018-0784-8.

23. Armontrout J., Gitlin D., Gutheil T. Do Consultation Psychiatrists, Forensic Psychiatrists, Psychiatry Trainees, and Health Care Lawyers Differ in Opinion on Gray Area Decision-Making Capacity Cases? A Vignette-Based Survey. Psychosomatics 2016; 57(5): 472-479, doi: 10.1016/j.psym.2016.04.002.

24. Skead N., Rogers S., Doraisamy J. Looking beyond the mirror: Psychological distress; disordered eating, weight and shape concerns; and maladaptive eating habits in lawyers and law students. Int. J. Law. Psychiatry 2018; 61: 90-102, doi: $10.1016 / j$. ijlp. 2018.06.002

25. Fuentes Chacón R.M., Simón Saiz M.J., Garrido Abejar M., Serrano Parra M.D., Larrañaga Rubio M.E., Yubero Jiménez S. Psychosomatic symptoms as an expression of the deterioration of the health-related quality of life in adolescents. Aten. Primaria 2018; 50(8): 493-499, doi: 10.1016/j.aprim.2017.06.009. 26. Desmedt M., Bergs J., Vertriest S., Vlayen A., Schrooten W., Hellings J., Vandijck D. Systematic psychometric review of self-reported instruments to assess patient safety culture in primary care. J. Adv. Nurs. 2018; 74(3): 539-549. doi: 10.1111/jan.13464.

27. El-Den S., Chen T., Gan Y., Wong E., O'Reilly C. The psychometric properties of depression screening tools in primary healthcare settings: A systematic review. J. Affect Disord. 2018; 225: 503-522, doi: 10.1016/j.jad.2017.08.060. 28. Soria V., Uribe J., Salvat-Pujol N., Palao D., Menchón J., Labad J. Psychoneuroimmunology of mental disorders. Rev. Psiquiatr. Salud. Ment. 2018; 11(2): 115-124, doi: 10.1016/j.rpsm.2017.07.006.

29. Innstrand S.T., Langballe E.M., Falkum E., Aasland O.G. Exploring within - and between-gender differences in burnout: 8 different occupational groups. Int. Arch. Occup. Environ. Health 2011; 84(7): 813-824, doi: 10.1007/ s00420-011-0667-y. 
30. Boland R., Rundell J., Epstein S., Gitlin D. Consultation-Liaison Psychiatry vs Psychosomatic Medicine: What's in a name? Psychosomatics 2018; 59(3): 207-210, doi: 10.1016/j.psym.2017.11.006.

31. Gałecki P., Talarowska M. Teoria zapalna depresji - najważniejsze fakty. Psychiatr. Pol. 2018; 52(3): 437-447, doi: 10.12740/PP/76863.

32. Sygit-Kowalkowska E., Weber-Rajek M., Herkt M., Ossowski R. Burnout in officers of the prison service units. The role of personality and selected professional characteristics. Med. Pr. 2017; 68(1): 85-94, doi: 10.13075 mp.5893.00499.

33. Skowroński B. Wypalenie zawodowe sądowych kuratorów zawodowych wykonujacych orzeczenia w sprawach karnych i rodzinnych. Resocjalizacja Polska 2016; 11: 184-209.

34. Liu J., Gill N., Teodorczuk A., Li Z., Sun J. The efficacy of cognitive behavioural therapy in somatoform disorders and medically unexplained physica symptoms: A meta-analysis of randomized controlled trials. J. Affect Disord. 2019; 245: 98-112, doi: 10.1016/j.jad.2018.10.114

35. Gałecki P., Talarowska M. Cognition, emotions, depression, inflammable processes - basic principles of the neurodevelopmental theory of depression. Neuropsychiatria i Neuropsychologia 2017; 12(1): 30-37, doi: 10.5114/ nan.2017.68899.

36. Żołnierczyk-Zreda D., Holas P. Psychospołeczne warunki pracy a depresja i zaburzenia depresyjne: przegląd badań. Med. Pr. 2018; 69(5): 573-581, doi $10.13075 / \mathrm{mp} .5893 .00703$
37. Driot D., Dupouy J. Management of first depression or generalized anxiety disorder in adults in primary care: A systematic metareview. Presse Med. 2017; 46(12 Pt 1): 1124-1138, doi: 10.1016/j.lpm.2017.10.010

38. Melin E., Svensson R., Thulesius H. Psychoeducation against depression, anxiety, alexithymia and fibromyalgia: a pilot study in primary care for patients on sick leave. Scand. J. Prim. Health Care. 2018; 36(2): 123-133, doi: 10.1080/02813432.2018.1459225.

39. Salazar-Fraile J., Sempere-Verdú E., Pérez-Hoyos S., Tabarés-Seisdedos R., Gómez-Beneyto M. Five Interpersonal Factors Are Predictive of the Response to Treatment of Major Depression With Antidepressants in Primary Care. Front Psychiatry. 2018; 9: 416, doi: 10.3389/fpsyt.2018.00416.

40. Haller H., Cramer H., Lauche R., Dobos G. Somatoform disorders and medically unexplained symptoms in primary care. Dtsch. Arztebl. Int. 2015;112(16): 279-287, doi: 10.3238 /arztebl.2015.0279.

41. Remes O., Wainwright N., Surtees P., Lafortune L., Khaw K., Brayne C. Generalised anxiety disorder and hospital admissions: findings from a large, population cohort study. BMJ Open. 2018; 8(10): e018539, doi: 10.1136/bmjopen-2017-018539.

42. Piontek K., Shedden-Mora M., Gladigau M., Kuby A., Löwe B. Diagnosis of somatoform disorders in primary care: diagnostic agreement, predictors, and comaprisons with depression and anxiety. BMC Psychiatry 2018; 18(1): 361 , doi: $10.1186 / \mathrm{s} 12888-018-1940-3$ 